\title{
Results of VAMAS Survey Regarding Microplastic Issues
}

Stefania Federici $i^{\S \#}$, Monika Rani $^{\S \#}$, Laura E. Depero ${ }^{\S \# *}$

$\S$ Department of Mechanical and Industrial Engineering, University of Brescia, via Branze, 38 25123 Brescia, Italy

\# Consorzio Interuniversitario Nazionale per la Scienza e Tecnologia dei Materiali (INSTM), via Giusti, 9 - 50121 Firenze, Italy

* corresponding author

laura.depero@unibs.it

KEYWORDS: Microplastics, nanoplastics, survey, VAMAS, standards

ABSTRACT: Trillions of tiny particles generated by our plastic-reliant society are polluting environments worldwide. An explosion of research has been devoted in the last years to detect, identify and quantify the microplastics, hidden not only in the oceans but also in the world's rivers, lakes, air, soil as well as food and organisms. Thus, we urgently need reliable standards to support the decision-maker to handle many issues related to this question. In this paper, the results of a VAMAS survey that involved 390 experts are presented and discussed. The inter-laboratory studies urgently needed in the next future are proposed.

\section{Graphical Abstract}

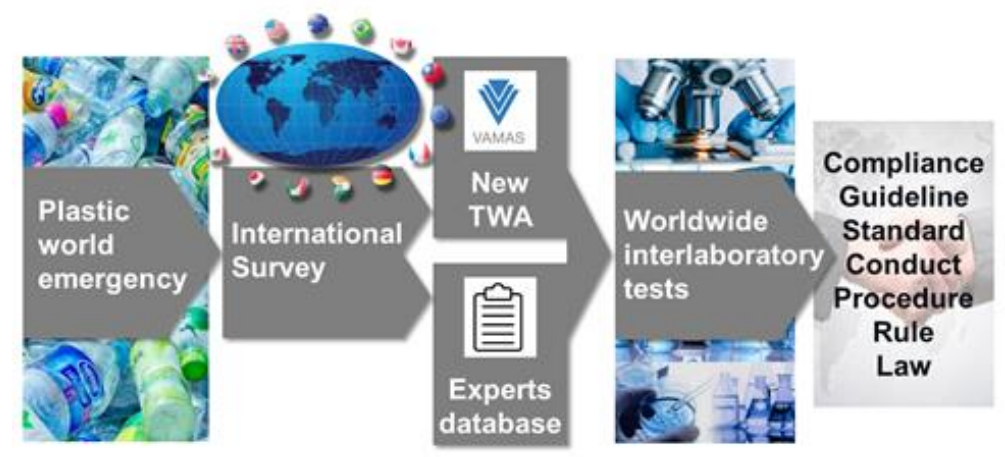




\section{Introduction}

Microplastics (MPs) derive from countless human-made products and are found in every environmental sector ${ }^{1,2,3}$. Below the micron, the term nano-plastics (NPs) should be used, although in general this distinction is not yet applied, at least by current regulations ${ }^{4}$. MPs and NPs have all anthropic origin and consist of mainly six different polymers: polyethylene terephthalate (indicated in the recycling codes as PET or PETE), high or low-density polyethylene (indicated respectively as PE-HD or HDPE and PE-LD or LDPE), polyvinyl chloride (PVC), polypropylene (PP), polystyrene $(\mathrm{PS})^{5}$. They originate from many everyday products (mainly cosmetics, synthetic fabrics, tyres) and are found in the environment principally due to the inadequate disposal of plastic waste and wear phenomena $^{3,6,7,8,9}$.

The presence of MPs in water bodies worldwide is increasing and scientists, risk-managers, politicians and, above all, the population, consider the related issue to be of great concern. It is now necessary to fully understand the level of risk to human health and ecosystems and, therefore, the necessary prevention and control actions ${ }^{10}$. MPs may reach surface water bodies by different routes, such as leaching of particles in soil or air to water bodies, transport of plastics disposed inadequately and also from untreated sewage drains, due to meteoric events and transported by effluent from sewage treatment plants ${ }^{11,7,12}$.

Therefore, it is a topic of primary interest and requires fundamental interdisciplinary research. There is a need to implement the necessary environmental policies to deal effectively with the potential environmental problems ${ }^{13,14}$.

In this context, proper scientific and technical dissemination to the various stakeholders, decisionmakers and the population should promote awareness of the issue, its origin, dissemination and extent, deepening the aspects still under discussion to provide a sound knowledge base and standards $\mathrm{s}^{15,16,17,18,19}$.

The risk of MPs for humans and aquatic organisms is still under discussion ${ }^{20,21,10}$. In fact, against the experimental evidence that shows how the MPs, ingested or breathed, can penetrate through the 
tissues of living organisms, their actual toxicity is still not assessed. Relevant are also potential impacts of the additives such as plasticisers and pigments $22,23,24,25,26$.

One of the major difficulties is the lack of standardisation of the tests for the evaluation of MPs. An effective strategy can be only achieved thanks to a clear scientific vision of the issues arising from MPs and NPs, allowing the development of common standards, and facilitating the agreement on international regulations.

MPs issues are addressed in the environmental legislation (with a particular focus on marine protection) and in the legislation dealing with products and product packaging. At a more general political level, in Europe, for instance, it is discussed in the plastic strategy ${ }^{27}$ and the European action plan for the circular economy, "Closing the loop"28, where, however, MPs and NPs are not explicitly mentioned $^{4}$. Due to the lack of reliable data, the precautionary principle has been part of the basis of the current regulation ${ }^{29}$.

There are currently no standardised and unambiguous methods for sampling MPs in the various environmental matrices, even if a lot of work has been done ${ }^{30,31,32,33,34}$. In such a complex scenario, it is necessary to know the matrix to be monitored and to carry out the proper sampling. The assessment of MPs is a multi-step process, including sample preparation (such as homogenisation or preconcentration), extraction, purification, identification, and quantification.

The composition of MPs plays a fundamental role in the precise knowledge and management of the problem of the relative environmental pollution. Unfortunately, any standard method for MPs identification has still been adopted. The characterisation of MPs can be performed by different chemical-physical techniques, each of which has advantages and disadvantages and through which it is possible to estimate different parameters. Among the different techniques, vibrational spectroscopies are attested as the most used techniques, because the analysis is fast, free of chemical reagents, cost-effective, and non-destructive ${ }^{35}$.

Knowledge of the sources, levels, environmental fate of MPs and the models are based on sampling and analysis, and reliable data are mandatory for the assessment of the management options ${ }^{36}$. 
Another critical aspect of assessing is the ability of MPs and NPs to act as carriers for other environmental contaminants ${ }^{37,38}$. MPs and NPs can be distributed differently from the physical particles in the different abiotic environmental compartments and constitute an additional risk factor for organisms through the diet and the breathing.

Further research is needed, which is still limited and scarcely comparable to clarify the transport mechanisms, the fate and potential for bioaccumulation of MPs and NPs in humans and to estimate the actual risks for each compartment.

The scientific community is rarely involved in the standardisation process since usually this is not considered part of the research. However, scientists should participate in this process when the assessment of experimental procedures is required. Indeed, a technical standard must correspond to the best practice assessed by experts, who must compare the results through inter-laboratory tests and understand the differences among results obtained by different techniques, different instruments, different laboratories. Standards can be used for proficiency tests to guarantee the reliably of the data, a mandatory requirement to any kind of analysis, and to help the operator to improve the laboratory performances. Moreover, the standards are relevant for the decision-makers, and scientists have the responsibility to give a contribution to their validation and assessment.

The standardisation process for the definition of material properties or new techniques is always based on research results (Figure 1). A new method then must be assessed first by intra- and then interlaboratory test to define the best procedure. After that, the standardisation process inside can begin. The standardisation is a mandatory step in the case of issues related to society, in particular in the case of health and environmental normative. 


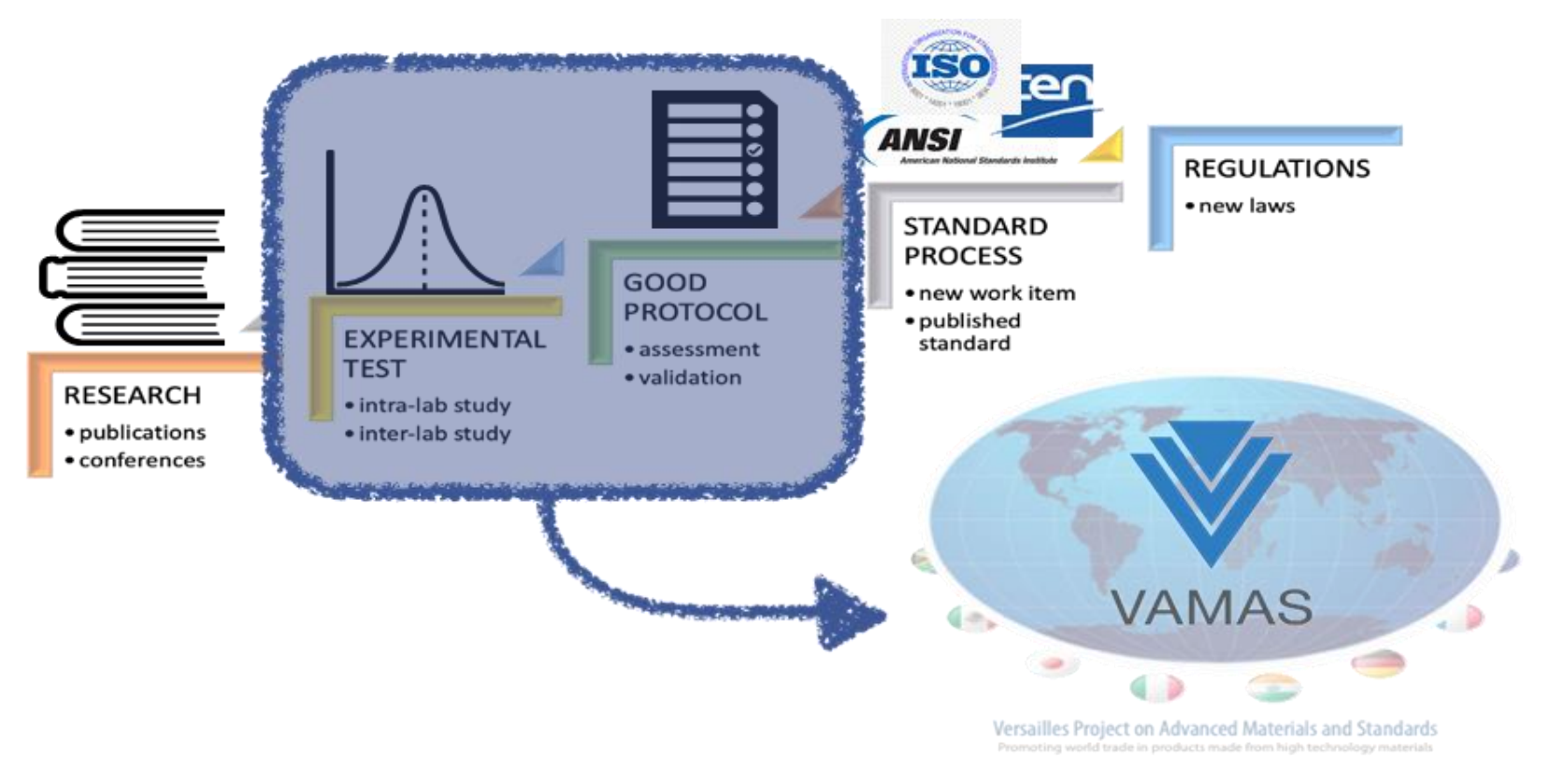

Figure 1. Standardisation Process

VAMAS, established in 1982, helps and speeds up the assessment and the optimisation of a harmonised procedure ${ }^{39}$. Indeed, these two steps are those often neglected by the scientific community, and VAMAS can internationally promote these actions. The scope of VAMAS includes all the steps necessary to define materials and properties: process, characterisation, and performances. Today it involves Australia, Brazil, Canada, China, Chinese Taipei, France, Germany, India, Italy, Japan, Mexico, Republic of Korea, South Africa, UK, USA, Mexico, and European Union.

Researchers of any countries can participate in the projects.

Why we need reliable standards for micro and nano plastics issues? Before coronavirus pandemic, plastic was considered one of the major environmental issues, together with global warming. Indeed, the production, demand and waste of plastics growth exponentially starting in the last century. According to the analysis of European plastics production, demand and waste data ${ }^{40}$, in 2020 more than 368 million tonnes have been produced and this number is expected to double it in the next ten years. The worldwide coronavirus emergency has made make it even worst. Since the pandemic started, there has been a significant increase in plastic waste, such as masks, gloves and gowns. New 
solutions to handle the waste and to find new materials with more sustainable properties are needed and must be assessed.

On the other side, researchers are very active in the field of MP issues. During the last 2 years (namely, 2019 and 2020), more than 230 reviews have been published about different topics related to MPs and NPs. As shown in Figure 2a, the number of papers in the last 15 years is growing exponentially. The research devoted to nano plastics has the same trend, even if there is an order of magnitude lower. There is also a strong correlation between MPs and NPs-related papers published in each country as depicted in Figure 2b.
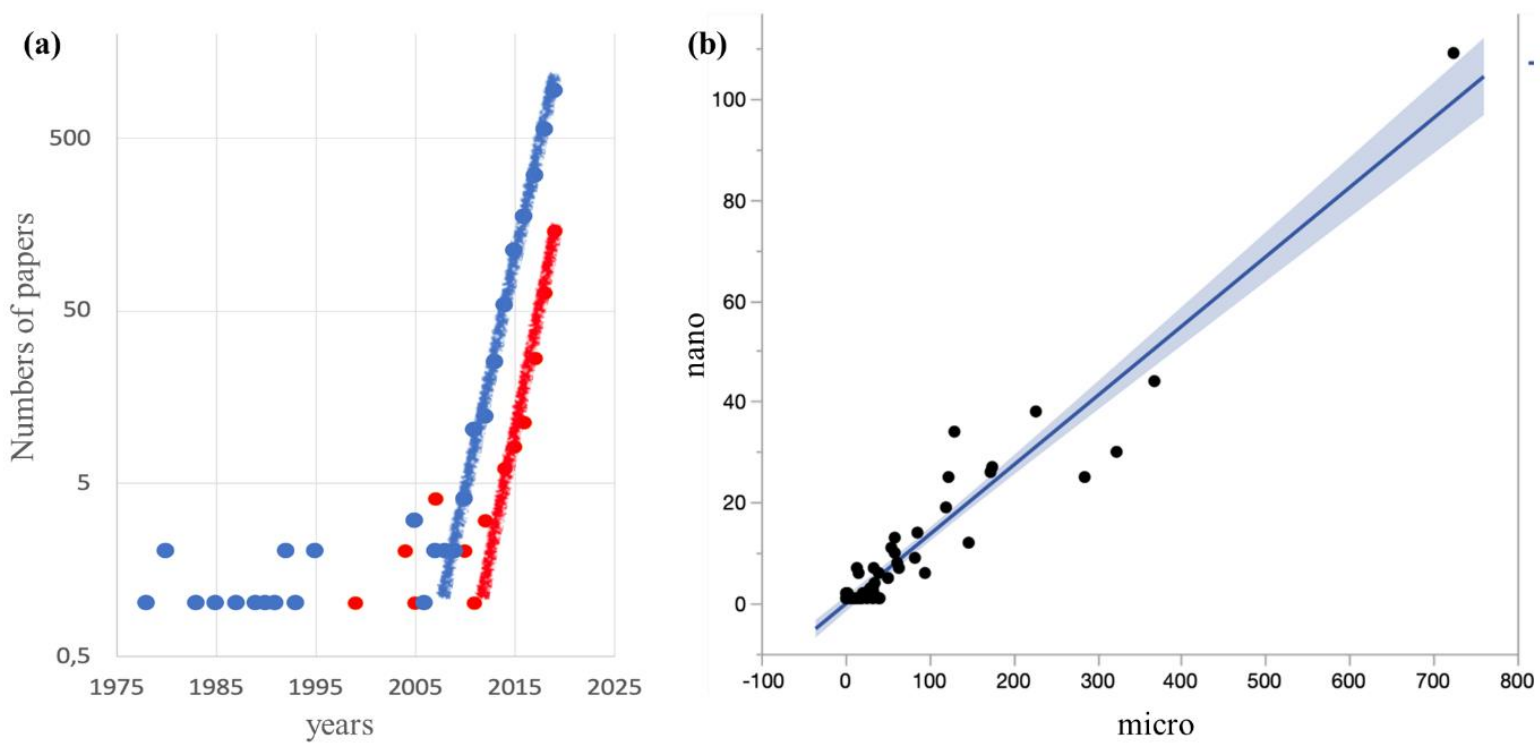

Figure 2. (a) SCOPUS publications about MPs (in blue) and NPs (in red). (b) Correlation between MPs and NPs-related papers.

The geographical distribution of the authors mirrors the international degree of the research in this field (Figure 3), confirming recent findings of detailed studies on global trends in MPs research ${ }^{13,41}$. 


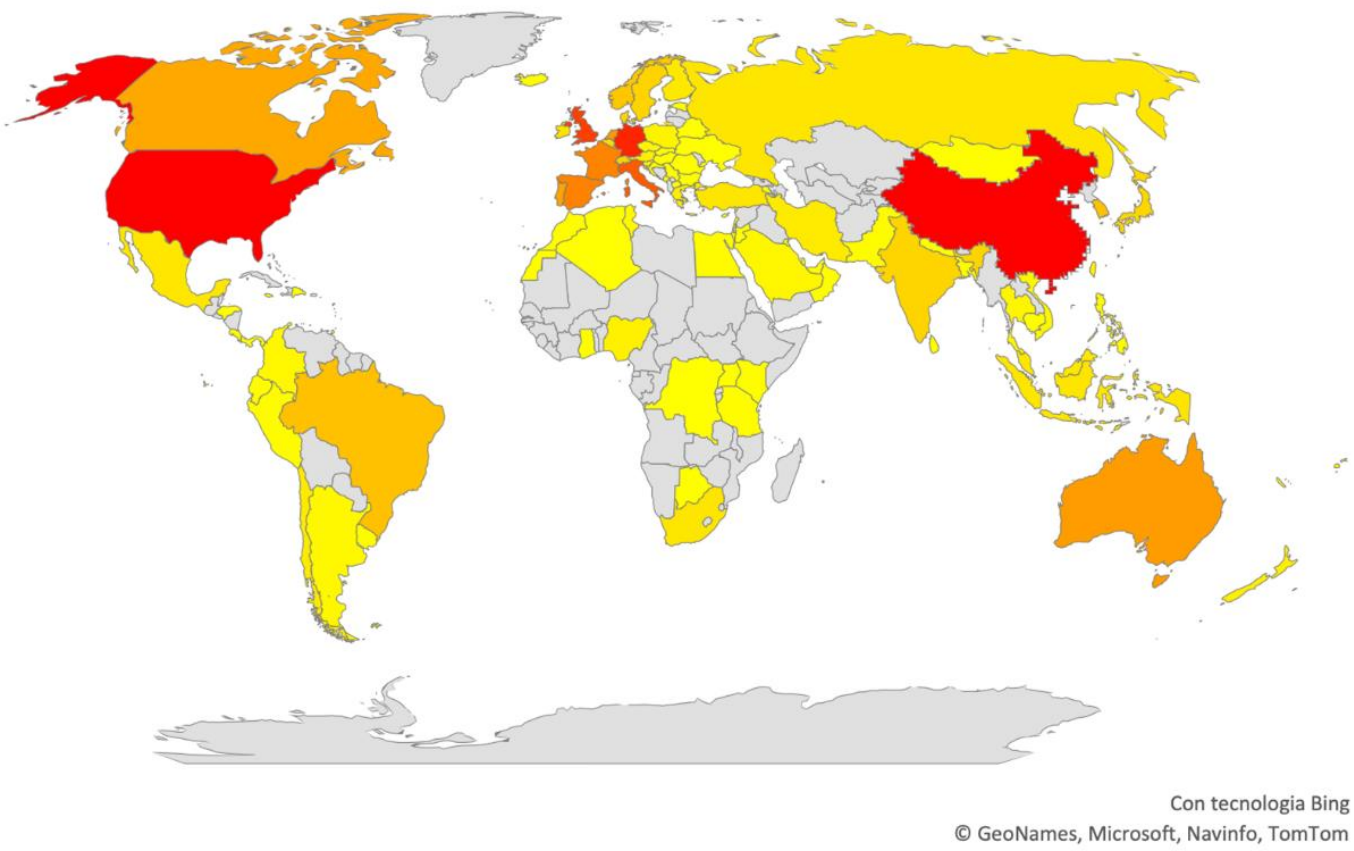

Figure 3. Total papers published in the world: micro and nano plastics.

There are already normative activities in the Technical Committee ISO/TC61-Plastic, in which there is a subcommittee devoted to the Environmental aspects and five working groups already established:

- Terminology, classifications and general guidance

- Biodegradability

- Biobased Plastics

- Characterisation of plastics leaked into the environment (including microplastics)

- Mechanical and chemical recycling

\section{The survey}

Last year, a survey was proposed to the scientific community to collect information about experts who work and plan to work on MP issues. 390 experts from 46 countries answered the survey. In this paper, we report a summary of the results. The survey is open and still available ${ }^{42}$. 


\subsection{General Information}

On the 390 experts answering the survey, about 50\% have worked with MPs. In Figure 4, the experts who answered the survey for each country are reported. The black columns indicate the experts who are involved in MP issues, the grey columns those who are planning to work in the field. In the red rectangle, there are countries where no experts who answered are yet involved.

We had the contribution of experts belonging to universities public research centres, private companies, metrological, and no-profit institutes. In Figure 5, it is shown that the large majority of the experts $(75 \%)$ belong to university.

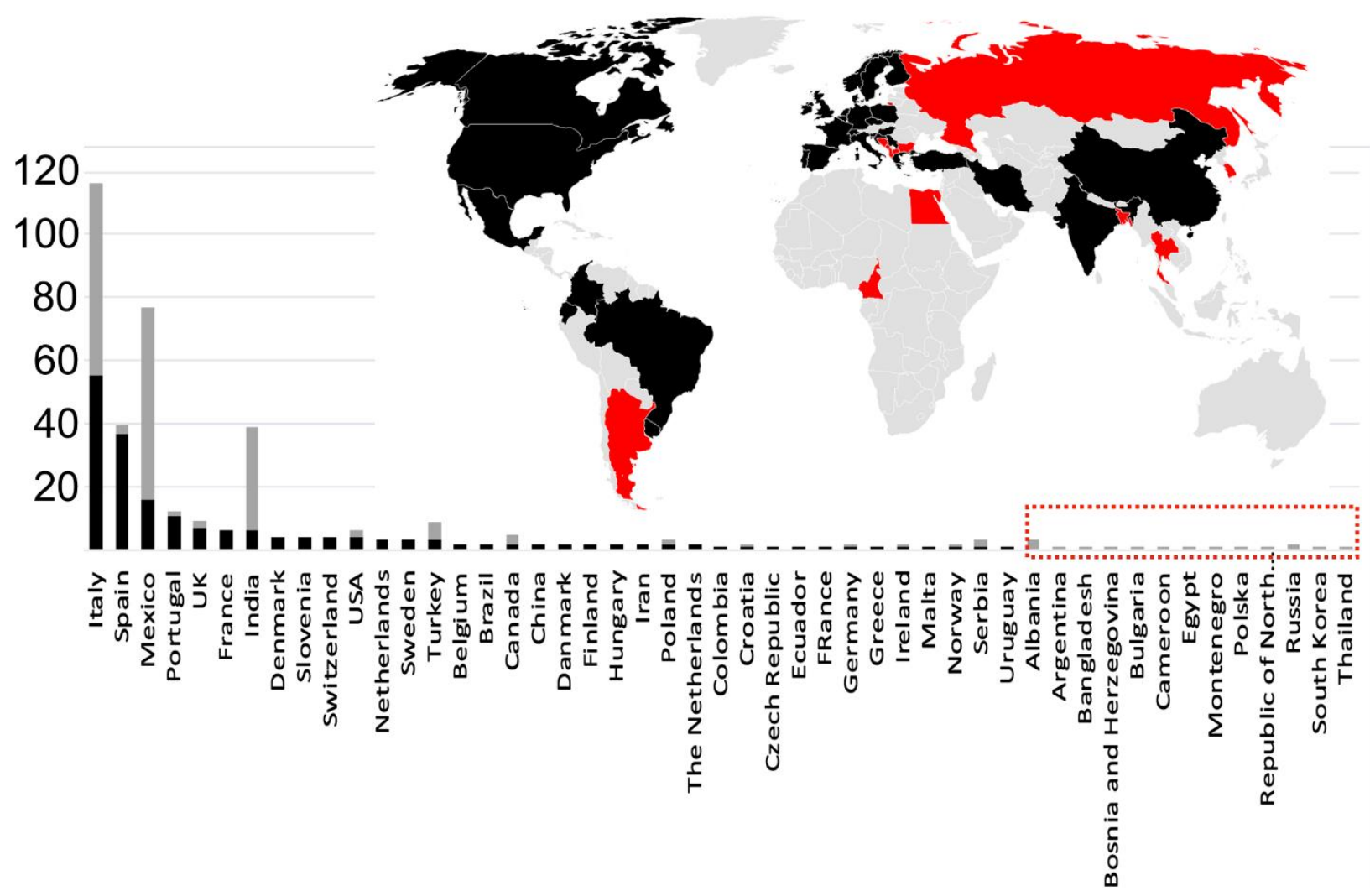

Figure 4. The experts of the countries who answered the survey. In the black are those who declared to have already experience in the field. In the red rectangle, there are countries where no experts who answered are yet involved. 


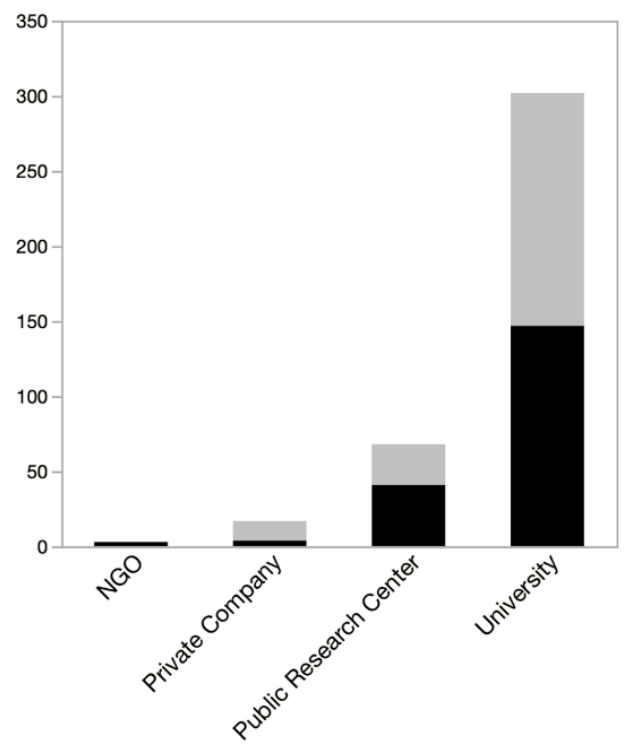

Figure 5. Experts organizations. In black the experts who declared to have already experience in the field.

\subsection{MP definition}

When standardisation procedures have to be assessed, definitions have to be clear and clarified ${ }^{43,44}$. Regarding microplastics, there are different definitions on the web and in the scientific publications. Thus, the first question of the survey regards the definition of MPs.

We proposed six different definitions ${ }^{45}$ :

A. Small pieces of plastic, less than $5 \mathrm{~mm}(0.2 \mathrm{in})$ in length;

B. According to their origin, primary, if produces to be of microscopic dimensions or secondary if resulting from degradation and fragmentation processes in the environment;

C. Plastic particles $<5 \mathrm{~mm}$ in diameter, which includes particles in the nano-size range $(1 \mathrm{~nm})$;

D. Lower size limits ranging from 1 to $20 \mu \mathrm{m}$;

E. Microplastics are any synthetic solid particle or polymeric matrix, with regular or irregular shape and with size ranging from $1 \mu \mathrm{m}$ to $5 \mathrm{~mm}$, of either primary or secondary manufacturing origin, which are insoluble in water; 
F. "Particles resulting from the degradation of plastic objects" and that "nano plastic exhibit a colloidal behaviour within size ranging from $1 \mathrm{~nm}$ to $1 \mu \mathrm{m} "$.

As shown in Figure 6, the majority of the expert chose option E as the best definition for MPs. Interestingly, the percentage of experts choosing different definition is independent by the country.
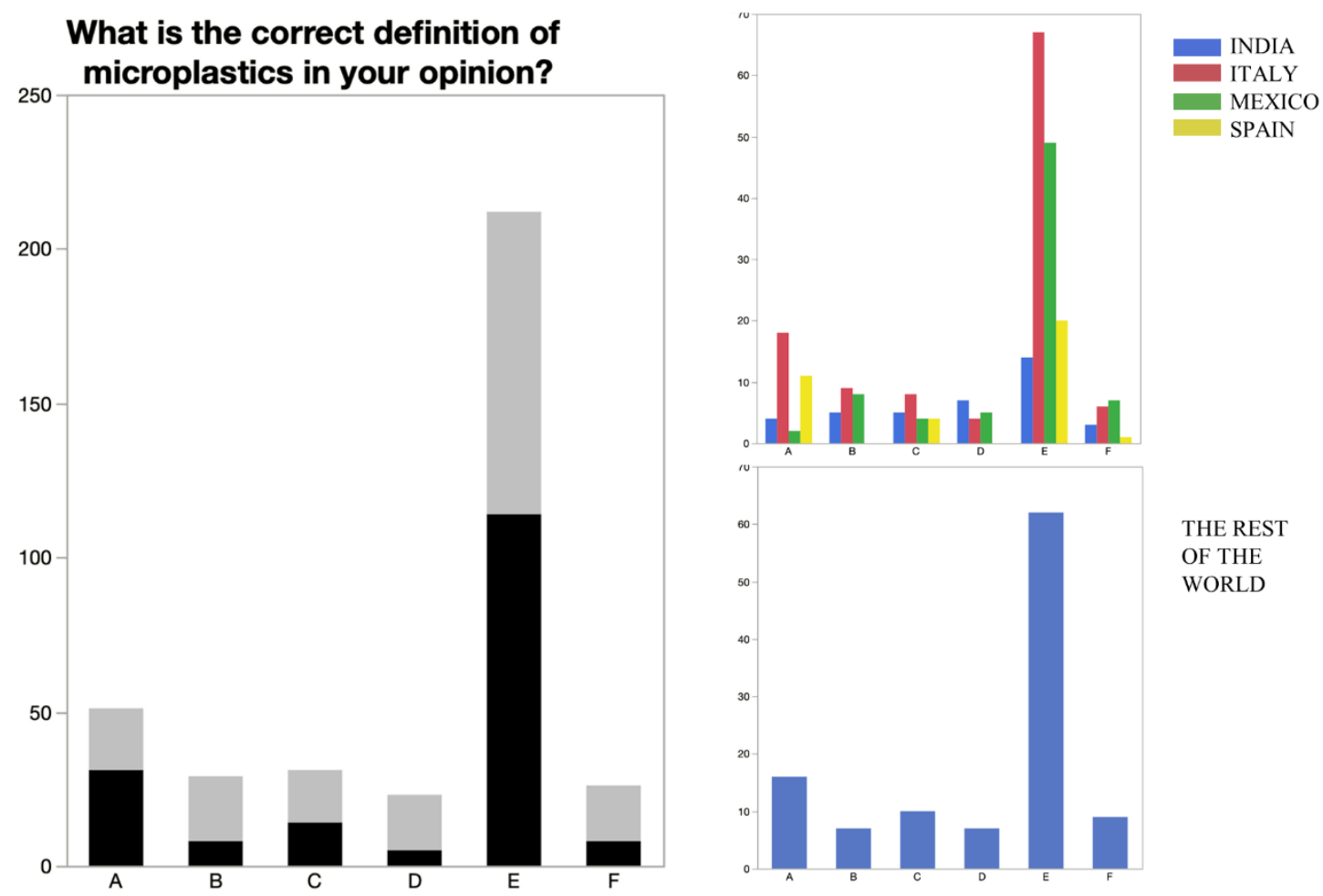

Figure 6. Definition of MPs, as given in the text. In black are those who declared to have already experience in the field.

The ISO technical report published in February $2020^{46}$ has given the definition for MP, large MP and nanoplastics $^{44}$. In Figure 7, the comparison of the survey results and the ISO definition. The term "large microplastic" is introduced for a particle with size between 1 to $5 \mathrm{~mm}$. Remarkably, following the ISO definition, $200 \mathrm{~nm}$ particles is defined as nanoplastic, but not as nanoparticle. 


\subsection{Criteria for defining MPs}

The second question is "What are the key criteria for defining microplastic?" Experts can make more than one choice. As expected, the majority chose as key criteria the size. In particular, 255 experts choose only the size. However, 27 experts choose the origin as the only key criterion (Figure 8).

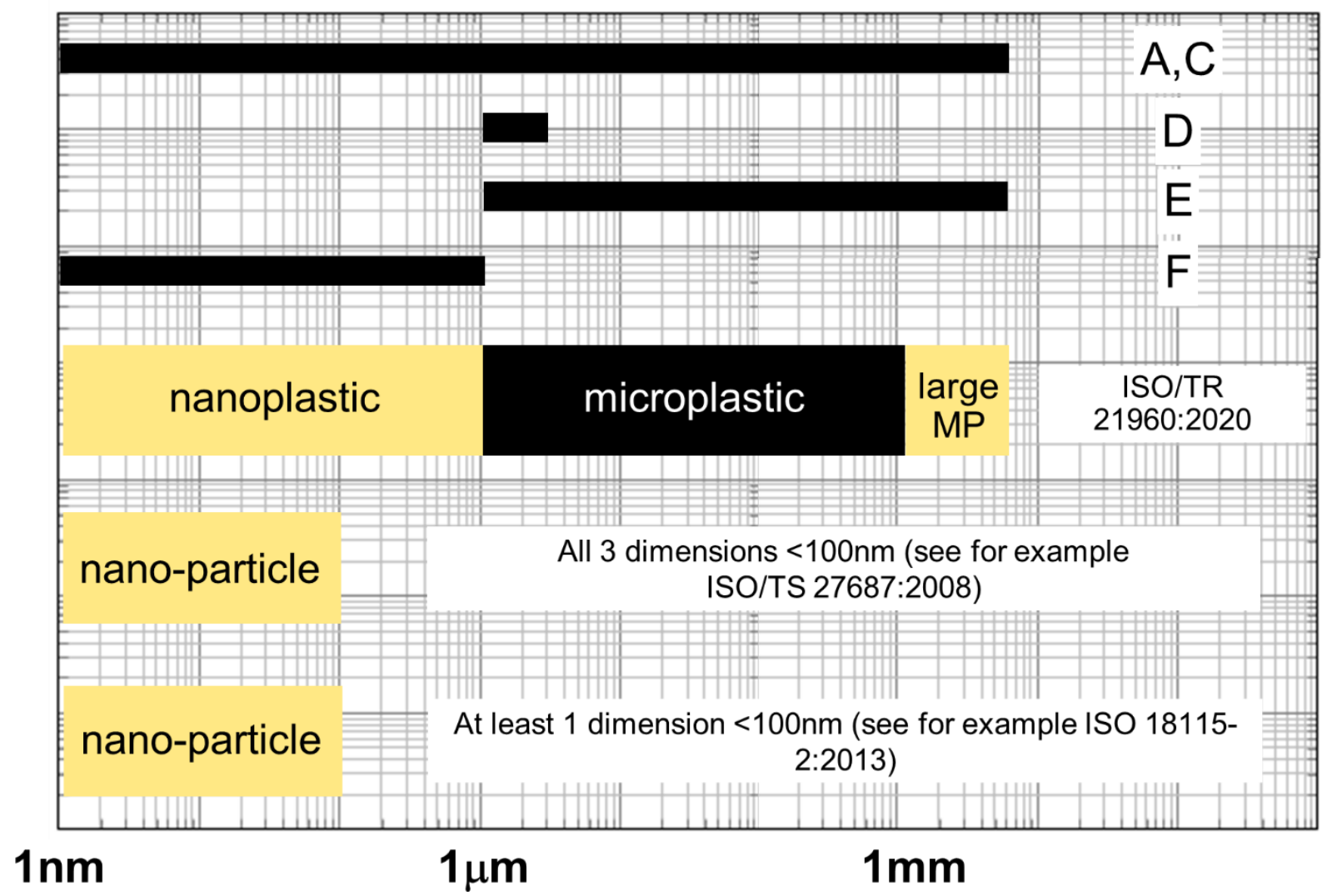

Figure 7. Definition of MPs given in the survey and in ISO. 


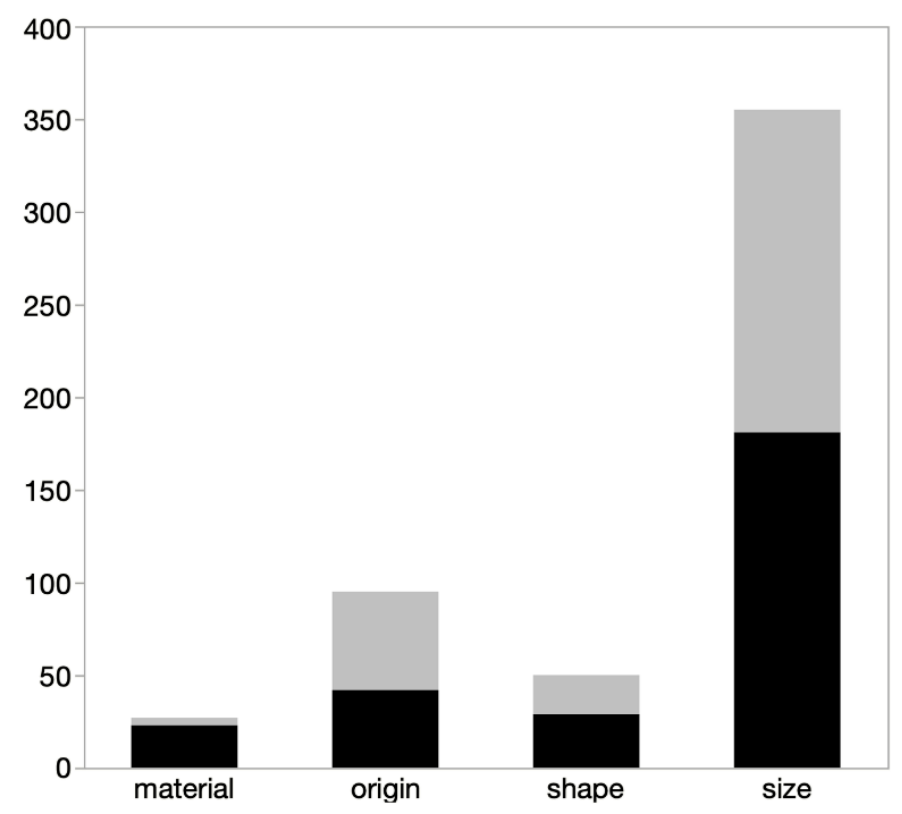

Figure 8. "What are the key criteria for defining microplastic?" In black are the experts who declared to have already experience in the field.

\subsection{MP properties}

The following question was: "what properties of microplastics are more/less critical for the environment?" The expert can score the properties from 0 (not relevant) to 6 (mandatory).

Most of the experts chose biodegradability as the most critical properties to be considered, followed by chemical and biological features. Mechanical and thermal properties are those considered less critical from most of the experts. In Figure 9, the scores given by the experts are shown. The black points in Figure 9(a) correspond to experts who declared to have already scientifically involved in MP matters. In Figure 9(b), are shown the choices of the experts who scored as mandatory the thermal prosperities. Interestingly, most of the experts who score 6 for thermal properties, considered also mandatory the definition of all the properties of the MPs. 


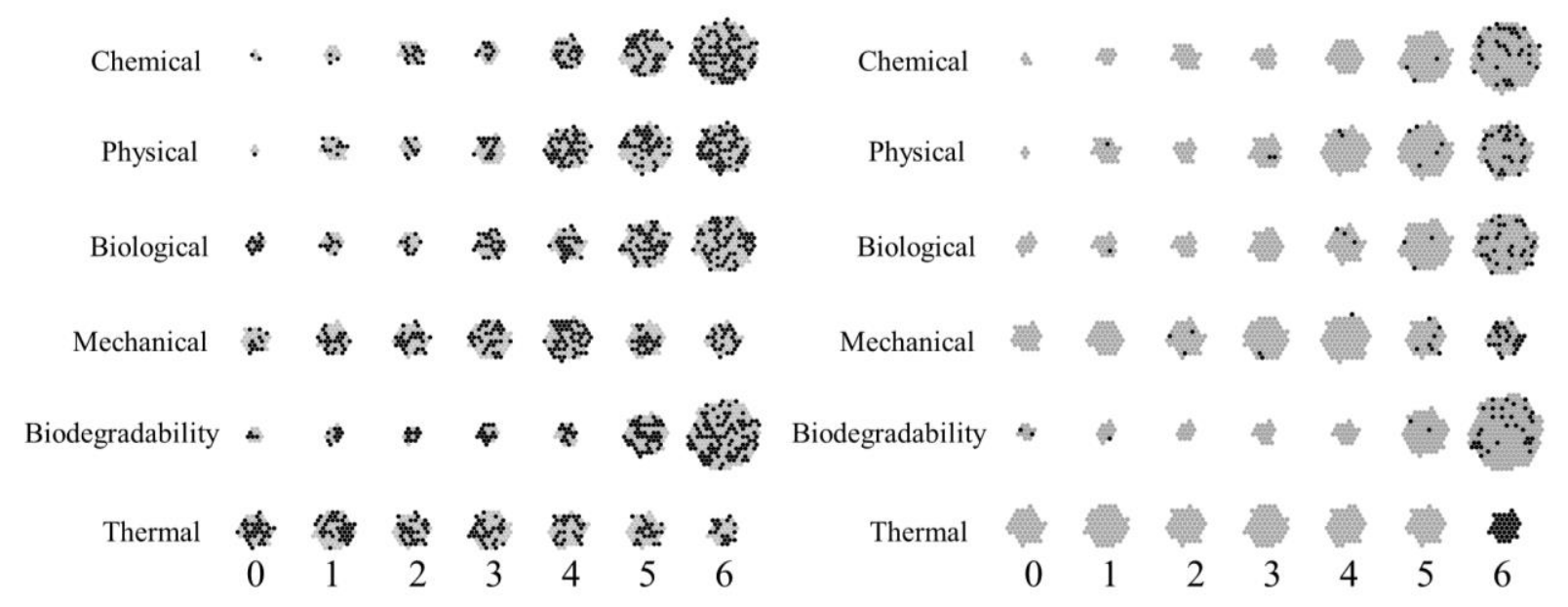

(A)

(B)

Figure 9. "What properties are far more/less critical for the environment?" (a) in black experts who declared to already have experience in the field. (b) in black the experts who score 6 to thermal properties.

In Figure 10, the correlation map among the scores given to the different properties is shown. Chemical, biological properties and biodegradability are considered the most critical. A strong correlation is clearly shown with the choices of mechanical and thermal properties. Some experts, answering the question gave interesting suggestions regarding other critical properties that have to be considered namely:

- Capacity to adsorb persistent organic pollutants (POPs);

- Transportation mechanisms;

- Biofilm formation around micro-particles;

- Degradation path;

- Absorption by living beings, ecotoxicity;

- Chemical additives in plastic production. 


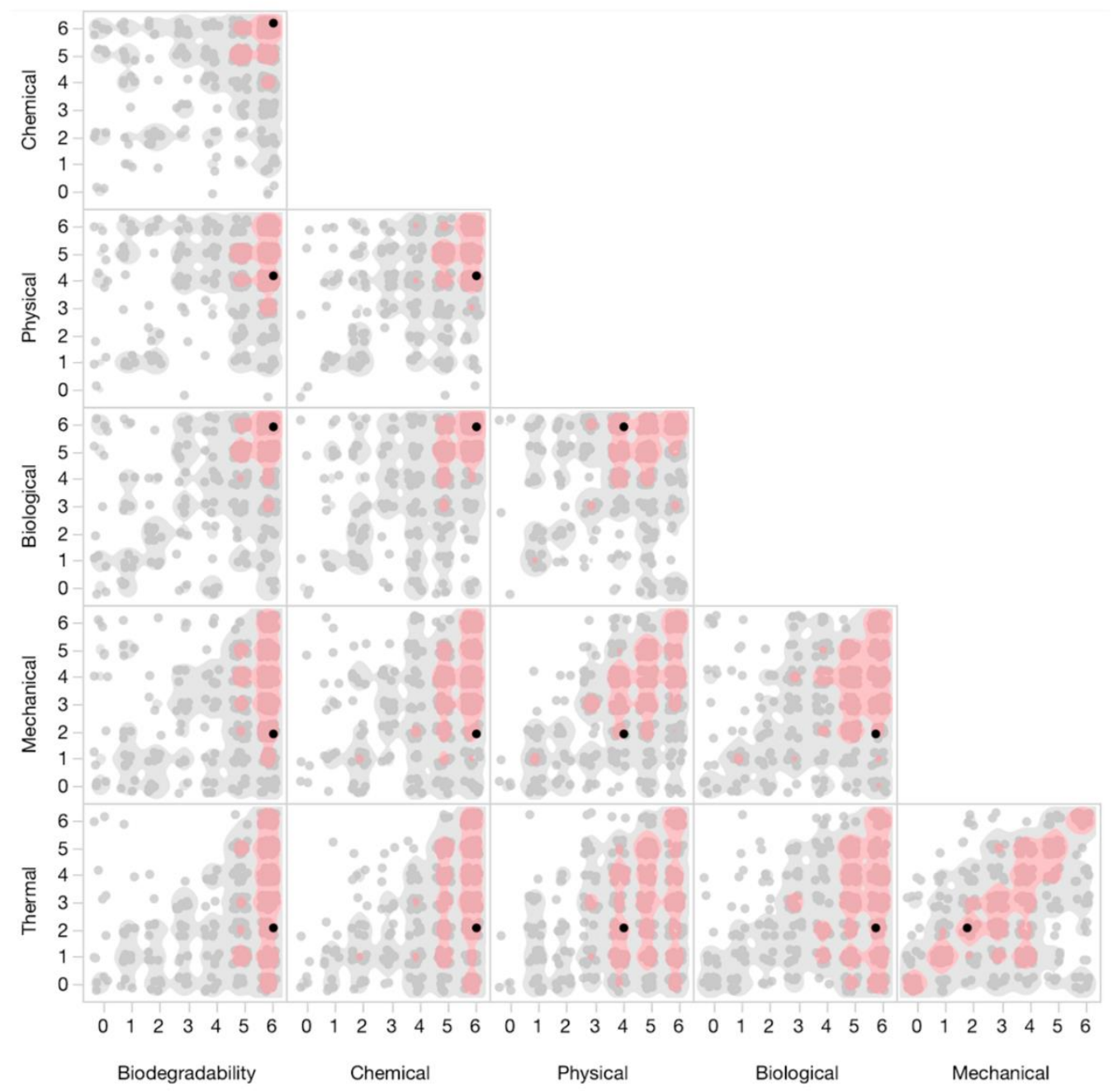

Figure 10. Correlation Map of the scores.

\subsection{Competences declared by the experts}

In Figure 11, the competences declared by the experts are reported. Other engineering competencies were added, as manufacturing, advanced water treatment, robotics, image processing.

Unfortunately, social and economic expertise are missing. Likely, when reliable data and models are available, also their contribution will be mandatory. In the Supplementary Material, the correlation between the competences of the experts and their scores are shown. There is not a significant correlation among the scores and the declared expertise. 
Based on the survey, experts had developed protocols to analysis MPs in all kinds of matrices, as waste, plants, animals, materials, and air. The majority declared to have developed protocols for the determination of chemical components in water (95) and sediment (67).

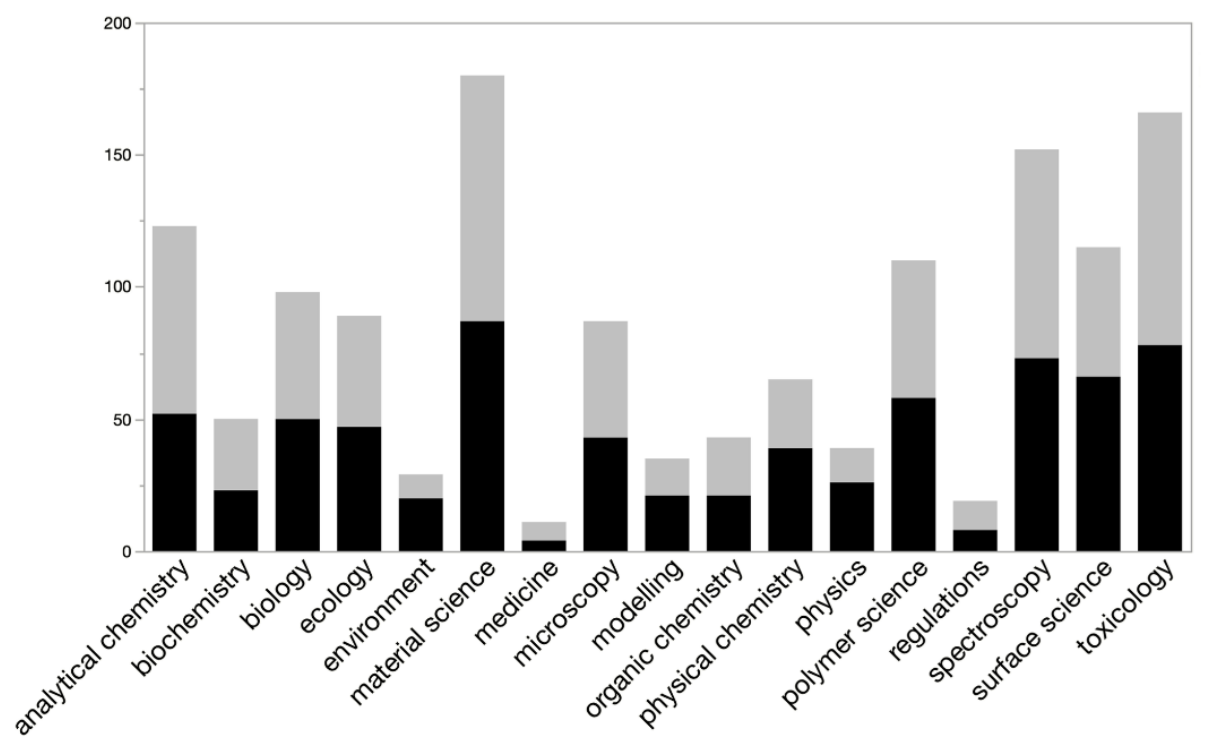

Figure 11. Competences of the experts. In black, the experts who declared to have already experience in the field.

\subsection{MP characterization techniques}

As expected by the bibliometric analysis ${ }^{13}$, the most used technique to characterise MPs is the infrared spectroscopy, with 111 experts declared to use it already. However, it has been recently outlined that most studies cannot be replicated due to missing experimental details ${ }^{47}$. Other techniques used by many experts are Raman spectroscopy ${ }^{48,49}$ and electron microscopy ${ }^{50,51}$, followed by DSC$\mathrm{TGA}^{52,53,54}, \mathrm{ICP}^{55}$ and Chromatography ${ }^{56}$ (see Figure 12). 


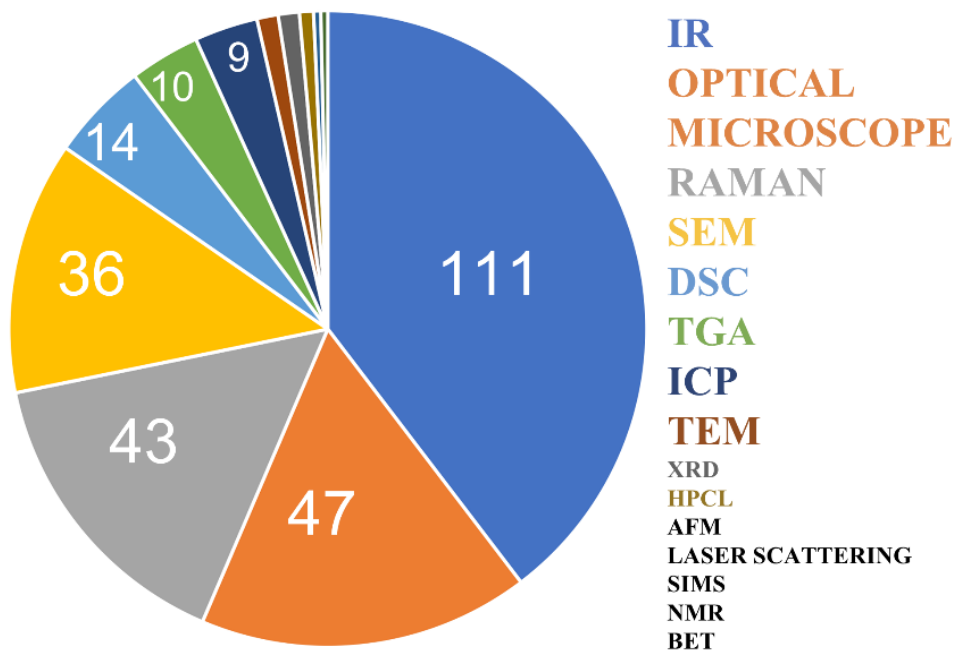

Figure 12. Distribution of MP characterization techniques

\subsection{Inter-laboratory activities}

The survey collected suggestions for inter-laboratory activities urgently needed, namely:

1. assessment of sampling in different matrices (air, waters and leachates, soils and sands, marine organisms, food) to avoid/limit sample contamination during sampling, storage, extraction and detection $57,58,59,60,61,62,63,64,65,66,67,68,69,70,71,72$;

2. definition of reference standard MPs;

3. definition of protocols for dispersion or homogenisation of the microplastics onto the test $\operatorname{media}^{68}$

4. detection, identification of the chemical components, classification $^{73,74,75,76,77,78,79,49,68,56,48,80,50,81,52}$;

5. quantification and size and mass fraction distribution in different environmental matrices $^{82,83,84,85,86}$;

6. biodegradation and degradation and aging $87,88,89,24,90,91,92$;

7. biological effect, evaluation of inflammation (and microbiota) in juvenile organisms (fish, mammals, birds, invertebrates), testing the transit time of microplastics through the gastrointestinal tract of marine animals, bioaccumulation in each type of tissue (fats, etc.), 
toxicity

assessment $14,93,94,95,96,97,98,99,100,101,102,103,104,105,106,107,108,109,110,111,112,113,114,115,116,117,118$;

8. assessment of sewage and waters treatment ${ }^{119,120,121,122,123,124,125,126,127,75,128,129,130,131 \text {; }}$

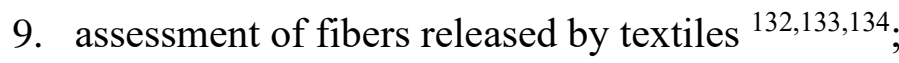

10. transportation models $135,102,123,136,5,137,138$;

11. isolation and identification of nano fraction in environmental samples including biota $139,140,141,142,143$

12. assessment of the impacts $144,145,5,75,8,146,147,148,149,150$

\section{Implications}

The scientific community involved in MP and NP issues is growing fast since potential drawbacks for the environment and possible for human health are relevant.

To have reliable data are mandatory for the society and, in particular, for the decision-makers.

Inter-laboratory study to assess the protocols for sampling, detection and modelling the phenomena should be a priority to the standardisation. The evaluation of the real dangers should be assessed and declined in legislation acts that should be shared by all the countries to be effective.

The new technical area of VAMAS has been proposed to give the scientific community an international platform to very and assessed all the scientific topics related to MPs and to support all the national and international projects in developing reliable protocols.

As a fallout of the survey, a database of international experts with very different competencies who are already involved or would like to work on MP issues is available. 


\section{AUTHOR INFORMATION}

\section{Corresponding Author}

*laura.depero@unibs.it,+390303715471.

\section{Author Contributions}

The manuscript was written through contributions of all authors.

\section{Funding Sources}

This research was funded by PON "R\&I" 2014-2020: SIRIMAP - SIstemi di Rilevamento dell'Inquinamento MArino da Plastiche e successivo recupero-riciclo (No. ARS01_01183) CUP D86C18000520008.

\section{Notes}

Authors declare no competing financial interest.

\section{ACKNOWLEDGMENTS}

We acknowledge the VAMAS Secretary, Dr. Sam Gnaniah, for spreading the survey in the scientific community and the colleagues who agreed to participate.

If you want to participate and be added in the expert database, the link is bit.ly/microplastic_survey

\section{References}

(1) Zhang, Q.; Xu, E. G.; Li, J.; Chen, Q.; Ma, L.; Zeng, E. Y.; Shi, H. A Review of Microplastics in Table Salt, Drinking Water, and Air: Direct Human Exposure. Environ. Sci. Technol. 2020, 54 (7), 3740-3751. https://doi.org/10.1021/acs.est.9b04535.

(2) Xu, C.; Zhang, B.; Gu, C.; Shen, C.; Yin, S.; Aamir, M.; Li, F. Are We Underestimating the Sources of Microplastic Pollution in Terrestrial Environment? J. Hazard. Mater. 2020, 400. https://doi.org/10.1016/j.jhazmat.2020.123228.

(3) Galafassi, S.; Nizzetto, L.; Volta, P. Plastic Sources: A Survey across Scientific and Grey Literature for Their Inventory and Relative Contribution to Microplastics Pollution in Natural 
Environments, with an Emphasis on Surface Water. Sci. Total Environ. 2019, 693. https://doi.org/10.1016/j.scitotenv.2019.07.305.

(4) Lam, C. S.; Ramanathan, S.; Carbery, M.; Gray, K.; Vanka, K. S.; Maurin, C.; Bush, R.; Palanisami, T. A Comprehensive Analysis of Plastics and Microplastic Legislation Worldwide. Water. Air. Soil Pollut. 2018, 229 (11). https://doi.org/10.1007/s11270-0184002-z.

(5) Kawecki, D.; Nowack, B. Polymer-Specific Modeling of the Environmental Emissions of Seven Commodity Plastics As Macro- and Microplastics. Environ. Sci. \&amp; Technol. 2019, 53 (16), 9664-9676. https://doi.org/10.1021/acs.est.9b02900.

(6) Li, C.; Busquets, R.; Campos, L. C. L. C. Assessment of Microplastics in Freshwater Systems: A Review. Sci. Total Environ. 2020, 707, 135578. https://doi.org/10.1016/j.scitotenv.2019.135578.

(7) Meng, Y.; Kelly, F. J.; Wright, S. L. Advances and Challenges of Microplastic Pollution in Freshwater Ecosystems: A UK Perspective. Environ. Pollut. 2020, 256. https://doi.org/10.1016/j.envpol.2019.113445.

(8) Wu, P.; Huang, J.; Zheng, Y.; Yang, Y.; Zhang, Y.; He, F.; Chen, H.; Quan, G.; Yan, J.; Li, T.; Li, T.; Gao, B. Environmental Occurrences, Fate, and Impacts of Microplastics. Ecotoxicol. Environ. Saf. 2019, 184. https://doi.org/10.1016/j.ecoenv.2019.109612.

(9) GESAMP. Sources, Fate and Effects of MP in the Marine Environment. J. Ser. GESAMP Reports Stud. 2015, 90, 98.

(10) European Commission. Environmental and Health Risks of Microplastic Pollution; 2019. https://doi.org/10.2777/54199.

(11) Uhl, W.; Eftekhardadkhah, M.; Svendsen, C. Mapping Microplastic in Norwegian Drinking Water, Norsk Vann Report 241/2018; 2018.

(12) Li, C.; Busquets, R.; Campos, L. C. Assessment of Microplastics in Freshwater Systems: A Review. Sci. Total Environ. 2020, 707. https://doi.org/10.1016/j.scitotenv.2019.135578. 
(13) Zhang, Y.; Pu, S.; Lv, X.; Gao, Y.; Ge, L. Global Trends and Prospects in Microplastics Research: A Bibliometric Analysis. J. Hazard. Mater. 2020, 400. https://doi.org/10.1016/j.jhazmat.2020.123110.

(14) Hale, R. C.; Seeley, M. E.; La Guardia, M. J.; Mai, L.; Zeng, E. Y. A Global Perspective on Microplastics. J. Geophys. Res. Ocean. 2020, 125 (1). https://doi.org/10.1029/2018JC014719.

(15) SAM. Microplastic Pollution: The Policy Context - Background Paper; 2018. https://doi.org/10.2777/25898.

(16) Carney Almroth, B.; Jutfelt, F.; Bour, A. Accurate Science Requires That We Base Our Work on Accurate Publications. Environ. Pollut. 2020, 261. https://doi.org/10.1016/j.envpol.2020.114238.

(17) Rist, S.; Carney Almroth, B.; Hartmann, N. B.; Karlsson, T. M. A Critical Perspective on Early Communications Concerning Human Health Aspects of Microplastics. Sci. Total Environ. 2018, 626, 720-726. https://doi.org/10.1016/j.scitotenv.2018.01.092.

(18) Syberg, K.; Hansen, S. F.; Christensen, T. B.; Khan, F. R. Risk Perception of Plastic Pollution: Importance of Stakeholder Involvement and Citizen Science; 2018; Vol. 58. https://doi.org/10.1007/978-3-319-61615-5_10.

(19) Mouneyrac, C.; Lagarde, F.; Châtel, A.; Khan, F. R.; Syberg, K.; Palmqvist, A. The Role of Laboratory Experiments in the Validation of Field Data; 2017; Vol. 75. https://doi.org/10.1016/bs.coac.2016.10.005.

(20) Chen, G.; Feng, Q.; Wang, J. Mini-Review of Microplastics in the Atmosphere and Their Risks to Humans. Sci. Total Environ. 2020, 703. https://doi.org/10.1016/j.scitotenv.2019.135504.

(21) Gao, D.; Li, X.-Y.; Liu, H.-T. Source, Occurrence, Migration and Potential Environmental Risk of Microplastics in Sewage Sludge and during Sludge Amendment to Soil. Sci. Total Environ. 2020, 742. https://doi.org/10.1016/j.scitotenv.2020.140355. 
(22) Campanale, C.; Massarelli, C.; Savino, I.; Locaputo, V.; Uricchio, V. F. A Detailed Review Study on Potential Effects of Microplastics and Additives of Concern on Human Health. Int. J. Environ. Res. Public Health 2020, 17 (4). https://doi.org/10.3390/ijerph17041212.

(23) Massos, A.; Turner, A. Cadmium, Lead and Bromine in Beached Microplastics. Environ. Pollut. 2017, 227, 139-145. https://doi.org/10.1016/j.envpol.2017.04.034.

(24) Luo, H.; Li, Y.; Zhao, Y.; Xiang, Y.; He, D.; Pan, X. Effects of Accelerated Aging on Characteristics, Leaching, and Toxicity of Commercial Lead Chromate Pigmented Microplastics. Environ. Pollut. 2019. https://doi.org/10.1016/j.envpol.2019.113475.

(25) Liu, H.; Liu, K.; Fu, H.; Ji, R.; Qu, X. Sunlight Mediated Cadmium Release from Colored Microplastics Containing Cadmium Pigment in Aqueous Phase. Environ. Pollut. 2020, 263. https://doi.org/10.1016/j.envpol.2020.114484.

(26) Guerranti, C.; Martellini, T.; Perra, G.; Scopetani, C.; Cincinelli, A. Microplastics in Cosmetics: Environmental Issues and Needs for Global Bans. Environ. Toxicol. Pharmacol. 2019, 68, 75-79. https://doi.org/10.1016/j.etap.2019.03.007.

(27) Excell, C.; Salcedo-La Viña, C.; Worker, J.; Moses, E. Legal Limits on Single-Use Plastics and Microplastics: A Global Review of National Laws and Regulation. United Nations Environ. Program. Nairobi, Kenya 2018, 1-118.

(28) EUR-Lex - 52015DC0614 - EN - EUR-Lex.

(29) Kentin, E.; Kaarto, H. An EU Ban on Microplastics in Cosmetic Products and the Right to Regulate. Rev. Eur. Comp. Int. Environ. Law 2018, 27 (3), 254-266. https://doi.org/10.1111/reel.12269.

(30) Stock, F.; Kochleus, C.; Bänsch-Baltruschat, B.; Brennholt, N.; Reifferscheid, G. Sampling Techniques and Preparation Methods for Microplastic Analyses in the Aquatic Environment - A Review. TrAC - Trends Anal. Chem. 2019, 113, 84-92. https://doi.org/10.1016/j.trac.2019.01.014.

(31) Bannick, C. G.; Szewzyk, R.; Ricking, M.; Schniegler, S.; Obermaier, N.; Barthel, A. K.; 
Altmann, K.; Eisentraut, P.; Braun, U. Development and Testing of a Fractionated Filtration for Sampling of Microplastics in Water. Water Res. 2019, 149, 650-658. https://doi.org/10.1016/j.watres.2018.10.045.

(32) Prata, J. C.; da Costa, J. P.; Duarte, A. C.; Rocha-Santos, T. Methods for Sampling and Detection of Microplastics in Water and Sediment: A Critical Review. TrAC - Trends Anal. Chem. 2019, 110, 150-159. https://doi.org/10.1016/j.trac.2018.10.029.

(33) Frias, J.; Pagter, E.; Nash, R.; O’Connor, I.; Carretero, O.; Filgueiras, A.; Viñas, L.; Gago, J.; Antunes, J.; Bessa, F.; Sobral, P.; Goruppi, A.; Tirelli, V.; Pedrotti, M. L.; Suaria, G.; Aliani, S.; Lopes, C.; Raimundo, J.; Caetano, M.; Palazzo, L.; de Lucia Giuseppe Andrea Camedda, A.; Muniategui, S.; Grueiro, G.; Fernandez, V.; Andrade, J.; Dris, R.; Laforsch, C.; ScholzBöttcher, B. M.; Gerdts, G. Standardised Protocol for Monitoring Microplastics in Sediments. JPI-Oceans BASEMAN Proj. 2018, No. May, 33. https://doi.org/10.13140/RG.2.2.36256.89601/1.

(34) Zhang, Y.; Kang, S.; Allen, S.; Allen, D.; Gao, T.; Sillanpää, M. Atmospheric Microplastics: A Review on Current Status and Perspectives. Earth-Science Rev. 2020, 203. https://doi.org/10.1016/j.earscirev.2020.103118.

(35) Rani, M.; Marchesi, C.; Federici, S.; Rovelli, G.; Alessandri, I.; Vassalini, I.; Ducoli, S.; Borgese, L.; Zacco, A.; Bilo, F.; Bontempi, E.; Depero, L. E. Miniaturized Near-Infrared (MicroNIR) Spectrometer in Plastic Waste Sorting. Materials (Basel). 2019, 12, 2740. https://doi.org/10.3390/ma12172740.

(36) Blettler, M. C. M.; Abrial, E.; Khan, F. R.; Sivri, N.; Espinola, L. A. Freshwater Plastic Pollution: Recognizing Research Biases and Identifying Knowledge Gaps. Water Res. 2018, 143, 416-424. https://doi.org/10.1016/j.watres.2018.06.015.

(37) Mammo, F. K.; Amoah, I. D.; Gani, K. M.; Pillay, L.; Ratha, S. K.; Bux, F.; Kumari, S. Microplastics in the Environment: Interactions with Microbes and Chemical Contaminants. Sci. Total Environ. 2020, 743. https://doi.org/10.1016/j.scitotenv.2020.140518. 
(38) Fred-Ahmadu, O. H.; Bhagwat, G.; Oluyoye, I.; Benson, N. U.; Ayejuyo, O. O.; Palanisami, T. Interaction of Chemical Contaminants with Microplastics: Principles and Perspectives. Sci. Total Environ. 2020, 706. https://doi.org/10.1016/j.scitotenv.2019.135978.

(39) Www.Vamas.Org. 2013.

(40) Plastics Europe. Plastics -The Facts 2020:An analysis of European plastics production, demand and waste data.

(41) Pauna, V. H.; Buonocore, E.; Renzi, M.; Russo, G. F.; Franzese, P. P. The Issue of Microplastics in Marine Ecosystems: A Bibliometric Network AnalysisPauna, V. H., Buonocore, E., Renzi, M., Russo, G. F., \& Franzese, P. P. (2019). The Issue of Microplastics in Marine Ecosystems: A Bibliometric Network Analysis. Marine Pollut. Mar. Pollut. Bull. 2019, 149. https://doi.org/10.1016/j.marpolbul.2019.110612.

(42) Bit.Ly/Microplastic_survey.

(43) Hartmann, N. B.; Hüffer, T.; Thompson, R. C.; Hassellöv, M.; Verschoor, A.; Daugaard, A. E.; Rist, S.; Karlsson, T.; Brennholt, N.; Cole, M.; Lusher, A. L.; Wagner, M. Are We Speaking the Same Language? Recommendations for a Definition and Categorization Framework for Plastic Debris. Environ. Sci. Technol. 2019, 53 (3), 1039-1047. https://doi.org/10.1021/acs.est.8b05297.

(44) Gigault, J.; Baudrimont, M.; Pascal, P. Current Opinion: What Is a Nanoplastic? Environ. Pollut. 2018, 235, 1030-1034. https://doi.org/10.1016/j.envpol.2018.01.024.

(45) Frias, J. P. G. L.; Nash, R. Microplastics: Finding a Consensus on the Definition. Mar. Pollut. Bull. 2019, 138 (November 2018), 145-147. https://doi.org/10.1016/j.marpolbul.2018.11.022.

(46) ISO/TR 21960:2020 Plastics — Environmental Aspects — State of Knowledge and Methodologies.

(47) Andrade, J. M.; Ferreiro, B.; López-Mahía, P.; Muniategui-Lorenzo, S. Standardization of the Minimum Information for Publication of Infrared-Related Data When Microplastics Are 
Characterized. Mar. Pollut. Bull. 2020, 154.

https://doi.org/10.1016/j.marpolbul.2020.111035.

(48) Araujo, C. F.; Nolasco, M. M.; Ribeiro, A. M. P.; Ribeiro-Claro, P. J. A. Identification of Microplastics Using Raman Spectroscopy: Latest Developments and Future Prospects. Water Res. 2018, 142, 426-440. https://doi.org/10.1016/j.watres.2018.05.060.

(49) Xu, J.-L.; Thomas, K. V; Luo, Z.; Gowen, A. A. FTIR and Raman Imaging for Microplastics Analysis: State of the Art, Challenges and Prospects. TrAC - Trends Anal. Chem. 2019, 119. https://doi.org/10.1016/j.trac.2019.115629.

(50) Silva, A. B.; Bastos, A. S.; Justino, C. I. L.; Duarte, A. C.; Rocha-santos, T. A. P. Microplastics in the Environment: Challenges in Analytical Chemistry - A Review. Anal. Chim. Acta 2018, 1017, 1-19. https://doi.org/10.1016/j.aca.2018.02.043.

(51) Schwaferts, C.; Niessner, R.; Elsner, M.; Ivleva, N. P. Methods for the Analysis of Submicrometer- and Nanoplastic Particles in the Environment. Trends Anal. Chem. 2019, 112, 52-65. https://doi.org/10.1016/j.trac.2018.12.014.

(52) Rodríguez Chialanza, M.; Sierra, I.; Pérez Parada, A.; Fornaro, L. Identification and Quantitation of Semi-Crystalline Microplastics Using Image Analysis and Differential Scanning Calorimetry. Environ. Sci. Pollut. Res. 2018, 16767-16775. https://doi.org/10.1007/s11356-018-1846-0.

(53) Becker, R.; Altmann, K.; Sommerfeld, T.; Braun, U. Quantification of Microplastics in a Freshwater Suspended Organic Matter Using Different Thermoanalytical Methods Outcome of an Interlaboratory Comparison. J. Anal. Appl. Pyrolysis 2020. https://doi.org/10.1016/j.jaap.2020.104829.

(54) Peñalver, R.; Arroyo-Manzanares, N.; López-García, I.; Hernández-Córdoba, M. An Overview of Microplastics Characterization by Thermal Analysis. Chemosphere 2020, 242. https://doi.org/10.1016/j.chemosphere.2019.125170.

(55) Bolea-Fernandez, E.; Rua-Ibarz, A.; Velimirovic, M.; Tirez, K.; Vanhaecke, F. Detection of 
Microplastics Using Inductively Coupled Plasma-Mass Spectrometry (ICP-MS) Operated in Single-Event Mode. J. Anal. At. Spectrom. 2020, 35 (3), 455-460.

https://doi.org/10.1039/c9ja00379g.

(56) Renner, G.; Schmidt, T. C.; Schram, J. Analytical Methodologies for Monitoring Micro(Nano)Plastics: Which Are Fit for Purpose? Curr. Opin. Environ. Sci. Heal. 2018, 1, 55-61. https://doi.org/10.1016/j.coesh.2017.11.001.

(57) La Nasa, J.; Biale, G.; Mattonai, M.; Modugno, F. Microwave-Assisted Solvent Extraction and Double-Shot Analytical Pyrolysis for the Quali-Quantitation of Plasticizers and Microplastics in Beach Sand Samples. J. Hazard. Mater. 2021, 401. https://doi.org/10.1016/j.jhazmat.2020.123287.

(58) Schirinzi, G. F.; Pedà, C.; Battaglia, P.; Laface, F.; Galli, M.; Baini, M.; Consoli, P.; Scotti, G.; Esposito, V.; Faggio, C.; Andaloro, F.; Romeo, T. A New Digestion Approach for the Extraction of Microplastics from Gastrointestinal Tracts (GITs) of the Common Dolphinfish (Coryphaena Hippurus) from the Western Mediterranean Sea. J. Hazard. Mater. 2020, 397. https://doi.org/10.1016/j.jhazmat.2020.122794.

(59) Prata, J. C.; Paço, A.; Reis, V.; da Costa, J. P.; Fernandes, A. J. S.; da Costa, F. M.; Duarte, A. C.; Rocha-Santos, T. Identification of Microplastics in White Wines Capped with Polyethylene Stoppers Using Micro-Raman Spectroscopy. Food Chem. 2020, 331. https://doi.org/10.1016/j.foodchem.2020.127323.

(60) Gong, J.; Xie, P. Research Progress in Sources, Analytical Methods, Eco-Environmental Effects, and Control Measures of Microplastics. Chemosphere 2020, 254. https://doi.org/10.1016/j.chemosphere.2020.126790.

(61) Han, X.; Lu, X.; Vogt, R. D. An Optimized Density-Based Approach for Extracting Microplastics from Soil and Sediment Samples. Environ. Pollut. 2019, 254. https://doi.org/10.1016/j.envpol.2019.113009.

(62) Bianco, V.; Memmolo, P.; Merola, F.; Carcagni, P.; Distante, C.; Ferraro, P. High-Accuracy 
Identification of Micro-Plastics by Holographic Microscopy Enabled Support Vector

Machine. In Progress in Biomedical Optics and Imaging - Proceedings of SPIE; 2019; Vol. 10887. https://doi.org/10.1117/12.2509515.

(63) Schirinzi, G. F.; Llorca, M.; Seró, R.; Moyano, E.; Barceló, D.; Abad, E.; Farré, M. Trace Analysis of Polystyrene Microplastics in Natural Waters. Chemosphere 2019, 236. https://doi.org/10.1016/j.chemosphere.2019.07.052.

(64) Bigalke, M.; Filella, M. Foreword to the Research Front on "Microplastics in Soils." Environ. Chem. 2019, 16 (1), 1-2. https://doi.org/10.1071/ENv16n1_FO.

(65) Prata, J. C.; da Costa, J. P.; Girão, A. V; Lopes, I.; Duarte, A. C.; Rocha-Santos, T. Identifying a Quick and Efficient Method of Removing Organic Matter without Damaging Microplastic Samples. Sci. Total Environ. 2019, 686, 131-139.

https://doi.org/10.1016/j.scitotenv.2019.05.456.

(66) Liu, M.; Song, Y.; Lu, S.; Qiu, R.; Hu, J.; Li, X.; Bigalke, M.; Shi, H.; He, D. A Method for Extracting Soil Microplastics through Circulation of Sodium Bromide Solutions. Sci. Total Environ. 2019, 691, 341-347. https://doi.org/10.1016/j.scitotenv.2019.07.144.

(67) Paturzo, M.; Merola, F.; Bianco, V.; Memmolo, P.; Miccio, L.; Mandracchia, B.; Ferraro, P. Detection and Sorting of Microplastics in Marine Environment by New Imaging Tools. In Proceedings of SPIE - The International Society for Optical Engineering; 2018; Vol. 10834. https://doi.org/10.1117/12.2319400.

(68) Mai, L.; Bao, L.-J.; Shi, L.; Wong, C. S.; Zeng, E. Y. A Review of Methods for Measuring Microplastics in Aquatic Environments. Environ. Sci. Pollut. Res. 2018, 25 (12), 11319 11332. https://doi.org/10.1007/s11356-018-1692-0.

(69) Karlsson, T. M.; Vethaak, A. D.; Almroth, B. C.; Ariese, F.; van Velzen, M.; Hassellöv, M.; Leslie, H. A. Screening for Microplastics in Sediment, Water, Marine Invertebrates and Fish: Method Development and Microplastic Accumulation. Mar. Pollut. Bull. 2017, 122 (1-2), 403-408. https://doi.org/10.1016/j.marpolbul.2017.06.081. 
(70) Bigalke, M.; Filella, M.; Fischer, D.; Muntwyler, A.; Scheurer, M.; Watts, B. Micro-and Nanoplastic Analysis in Soils. Chimia (Aarau). 2018, 72 (12), 901. https://doi.org/10.2533/chimia.2018.901.

(71) Besley, A.; Vijver, M. G.; Behrens, P.; Bosker, T. A Standardized Method for Sampling and Extraction Methods for Quantifying Microplastics in Beach Sand. Mar. Pollut. Bull. 2017, 114 (1), 77-83. https://doi.org/10.1016/j.marpolbul.2016.08.055.

(72) Catarino, A. I.; Thompson, R.; Sanderson, W.; Henry, T. B. Development and Optimization of a Standard Method for Extraction of Microplastics in Mussels by Enzyme Digestion of Soft Tissues. Environ. Toxicol. Chem. 2017, 36 (4), 947-951. https://doi.org/10.1002/etc.3608.

(73) Szymańska, M.; Obolewski, K. Microplastics as Contaminants in Freshwater Environments: A Multidisciplinary Review. Ecohydrol. Hydrobiol. 2020. https://doi.org/10.1016/j.ecohyd.2020.05.001.

(74) Huang, H.; Qureshi, J. U.; Liu, S.; Sun, Z.; Zhang, C.; Wang, H. Hyperspectral Imaging as a Potential Online Detection Method of Microplastics. Bull. Environ. Contam. Toxicol. 2020. https://doi.org/10.1007/s00128-020-02902-0.

(75) Barceló, D.; Picó, Y. Microplastics in the Global Aquatic Environment: Analysis, Effects, Remediation and Policy Solutions. J. Environ. Chem. Eng. 2019, 7 (5). https://doi.org/10.1016/j.jece.2019.103421.

(76) Kedzierski, M.; Falcou-Préfol, M.; Kerros, M. E.; Henry, M.; Pedrotti, M. L.; Bruzaud, S. A Machine Learning Algorithm for High Throughput Identification of FTIR Spectra: Application on Microplastics Collected in the Mediterranean Sea. Chemosphere 2019, 234, 242-251. https://doi.org/10.1016/j.chemosphere.2019.05.113.

(77) Gauci, A.; Deidun, A.; Montebello, J.; Abela, J.; Galgani, F. Automating the Characterisation of Beach Microplastics through the Application of Image Analyses. Ocean Coast. Manag. 2019, 182. https://doi.org/10.1016/j.ocecoaman.2019.104950. 
(78) Bordós, G.; Urbányi, B.; Micsinai, A.; Kriszt, B.; Palotai, Z.; Szabó, I.; Hantosi, Z.; Szoboszlay, S. Identification of Microplastics in Fish Ponds and Natural Freshwater Environments of the Carpathian Basin, Europe. Chemosphere 2019, 216, 110-116. https://doi.org/10.1016/j.chemosphere.2018.10.110.

(79) Gillibert, R.; Balakrishnan, G.; Deshoules, Q.; Tardivel, M.; Magazzù, A.; Donato, M. G.; Maragò, O. M.; Lamy De La Chapelle, M.; Colas, F.; Lagarde, F.; Lagarde, F.; Gucciardi, P. G. Raman Tweezers for Small Microplastics and Nanoplastics Identification in Seawater. Environ. Sci. Technol. 2019, 53 (15), 9003-9013. https://doi.org/10.1021/acs.est.9b03105.

(80) Lanctôt, C. M.; Al-Sid-Cheikh, M.; Catarino, A. I.; Cresswell, T.; Danis, B.; Karapanagioti, H. K.; Mincer, T.; Oberhänsli, F.; Swarzenski, P.; Tolosa, I.; Tolosa, I.; Metian, M. Application of Nuclear Techniques to Environmental Plastics Research. J. Environ. Radioact. 2018, 192, 368-375. https://doi.org/10.1016/j.jenvrad.2018.07.019.

(81) Anger, P. M.; von der Esch, E.; Baumann, T.; Elsner, M.; Niessner, R.; Ivleva, N. P. Raman Microspectroscopy as a Tool for Microplastic Particle Analysis. TrAC - Trends in Analytical Chemistry. 2018. https://doi.org/10.1016/j.trac.2018.10.010.

(82) Castelvetro, V.; Corti, A.; Bianchi, S.; Ceccarini, A.; Manariti, A.; Vinciguerra, V. Quantification of Poly(Ethylene Terephthalate) Micro- and Nanoparticle Contaminants in Marine Sediments and Other Environmental Matrices. J. Hazard. Mater. 2020, 385. https://doi.org/10.1016/j.jhazmat.2019.121517.

(83) Lorenzo-Navarro, J.; Castrillon-Santana, M.; Santesarti, E.; De Marsico, M.; Martinez, I.; Raymond, E.; Gomez, M.; Herrera, A. SMACC: A System for Microplastics Automatic Counting and Classification. IEEE Access 2020, 8, 25249-25261. https://doi.org/10.1109/ACCESS.2020.2970498.

(84) Shabaka, S. H.; Marey, R. S.; Ghobashy, M.; Abushady, A. M.; Ismail, G. A.; Khairy, H. M. Thermal Analysis and Enhanced Visual Technique for Assessment of Microplastics in Fish from an Urban Harbor, Mediterranean Coast of Egypt. Mar. Pollut. Bull. 2020, 159. 
https://doi.org/10.1016/j.marpolbul.2020.111465.

(85) Strungaru, S. A.; Jijie, R.; Nicoara, M.; Plavan, G.; Faggio, C. Micro- (Nano) Plastics in Freshwater Ecosystems: Abundance, Toxicological Impact and Quantification Methodology. TrAC - Trends Anal. Chem. 2019, 110, 116-128. https://doi.org/10.1016/j.trac.2018.10.025.

(86) David, J.; Steinmetz, Z.; Kučerík, J.; Schaumann, G. E. Quantitative Analysis of Poly(Ethylene Terephthalate) Microplastics in Soil via Thermogravimetry-Mass Spectrometry. Anal. Chem. 2018, 90 (15), 8793-8799. https://doi.org/10.1021/acs.analchem.8b00355.

(87) Oberbeckmann, S.; Labrenz, M. Marine Microbial Assemblages on Microplastics: Diversity, Adaptation, and Role in Degradation. Ann. Rev. Mar. Sci. 2020, 12, 209-232. https://doi.org/10.1146/annurev-marine-010419-010633.

(88) Winkler, A.; Santo, N.; Ortenzi, M. A.; Bolzoni, E.; Bacchetta, R.; Tremolada, P. Does Mechanical Stress Cause Microplastic Release from Plastic Water Bottles? Water Res. 2019, 166. https://doi.org/10.1016/j.watres.2019.115082.

(89) Guo, X.; Wang, J. The Chemical Behaviors of Microplastics in Marine Environment: A Review. Mar. Pollut. Bull. 2019, 142, 1-14. https://doi.org/10.1016/j.marpolbul.2019.03.019.

(90) Lago-Vila, M.; Arenas-Lago, D.; Rodríguez-Seijo, A.; Andrade, M. L.; Vega, F. A. Ability of Cytisus Scoparius for Phytoremediation of Soils from a Pb/Zn Mine: Assessment of Metal Bioavailability and Bioaccumulation. J. Environ. Manage. 2019, 235, 152-160. https://doi.org/10.1016/j.jenvman.2019.01.058.

(91) González-Pleiter, M.; Tamayo-Belda, M.; Pulido-Reyes, G.; Amariei, G.; Leganés, F.; Rosal, R.; Fernández-Piñas, F. Secondary Nanoplastics Released from a Biodegradable Microplastic Severely Impact Freshwater Environments. Environ. Sci. Nano 2019, 6 (5), 1382-1392. https://doi.org/10.1039/c8en01427b.

(92) Davranche, M.; Veclin, C.; Pierson-Wickmann, A.-C.; El Hadri, H.; Grassl, B.; Rowenczyk, L.; Dia, A.; Ter Halle, A.; Blancho, F.; Reynaud, S.; Reynaud, S.; Gigault, J. Are 
Nanoplastics Able to Bind Significant Amount of Metals? The Lead Example. Environ.

Pollut. 2019, 249, 940-948. https://doi.org/10.1016/j.envpol.2019.03.087.

(93) Wang, L.; Wu, W.-M.; Bolan, N. S.; Tsang, D. C. W.; Li, Y.; Qin, M.; Hou, D.

Environmental Fate, Toxicity and Risk Management Strategies of Nanoplastics in the Environment: Current Status and Future Perspectives. J. Hazard. Mater. 2021, 401. https://doi.org/10.1016/j.jhazmat.2020.123415.

(94) Silva, M. S. S.; Oliveira, M.; Lopéz, D.; Martins, M.; Figueira, E.; Pires, A. Do Nanoplastics Impact the Ability of the Polychaeta Hediste Diversicolor to Regenerate? Ecol. Indic. 2020, 110. https://doi.org/10.1016/j.ecolind.2019.105921.

(95) Pirsaheb, M.; Hossini, H.; Makhdoumi, P. Review of Microplastic Occurrence and Toxicological Effects in Marine Environment: Experimental Evidence of Inflammation. Process Saf. Environ. Prot. 2020, 142, 1-14. https://doi.org/10.1016/j.psep.2020.05.050.

(96) Bour, A.; Sturve, J.; Höjesjö, J.; Carney Almroth, B. Microplastic Vector Effects: Are Fish at Risk When Exposed via the Trophic Chain? Front. Environ. Sci. 2020, 8. https://doi.org/10.3389/fenvs.2020.00090.

(97) Yong, C. Q. Y.; Valiyaveetill, S.; Tang, B. L. Toxicity of Microplastics and Nanoplastics in Mammalian Systems. Int. J. Environ. Res. Public Health 2020, 17 (5). https://doi.org/10.3390/ijerph17051509.

(98) Casabianca, S.; Capellacci, S.; Penna, A.; Cangiotti, M.; Fattori, A.; Corsi, I.; Ottaviani, M. F.; Carloni, R. Physical Interactions between Marine Phytoplankton and PET Plastics in Seawater. Chemosphere 2020, 238. https://doi.org/10.1016/j.chemosphere.2019.124560.

(99) Tsangaris, C.; Digka, N.; Valente, T.; Aguilar, A.; Borrell, A.; de Lucia, G. A.; Gambaiani, D.; Garcia-Garin, O.; Kaberi, H.; Martin, J.; Wongdontree, P.; Matiddi, M. Using Boops Boops (Osteichthyes) to Assess Microplastic Ingestion in the Mediterranean Sea. Mar. Pollut. Bull. 2020, 158. https://doi.org/10.1016/j.marpolbul.2020.111397.

(100) Bringer, A.; Thomas, H.; Prunier, G.; Dubillot, E.; Bossut, N.; Churlaud, C.; Clérandeau, C.; 
Le Bihanic, F.; Cachot, J. High Density Polyethylene (HDPE) Microplastics Impair Development and Swimming Activity of Pacific Oyster D-Larvae, Crassostrea Gigas, Depending on Particle Size. Environ. Pollut. 2020, 260. https://doi.org/10.1016/j.envpol.2020.113978.

(101) Pereao, O.; Opeolu, B.; Fatoki, O. Microplastics in Aquatic Environment: Characterization, Ecotoxicological Effect, Implications for Ecosystems and Developments in South Africa. Environ. Sci. Pollut. Res. 2020, 27 (18), 22271-22291. https://doi.org/10.1007/s11356-02008688-2.

(102) Du, J.; Zhou, Q.; Li, H.; Xu, S.; Wang, C.; Fu, L.; Tang, J. Environmental Distribution, Transport and Ecotoxicity of Microplastics: A Review. J. Appl. Toxicol. 2020. https://doi.org/10.1002/jat.4034.

(103) Jaikumar, G.; Brun, N. R.; Vijver, M. G.; Bosker, T. Reproductive Toxicity of Primary and Secondary Microplastics to Three Cladocerans during Chronic Exposure. Environ. Pollut. 2019, 249, 638-646. https://doi.org/10.1016/j.envpol.2019.03.085.

(104) Ferreira, I.; Venâncio, C.; Lopes, I.; Oliveira, M. Nanoplastics and Marine Organisms: What Has Been Studied? Environ. Toxicol. Pharmacol. 2019, 67 (November 2018), 1-7. https://doi.org/10.1016/j.etap.2019.01.006.

(105) Botterell, Z. L. R.; Beaumont, N.; Dorrington, T.; Steinke, M.; Thompson, R. C.; Lindeque, P. K. Bioavailability and Effects of Microplastics on Marine Zooplankton: A Review. Environ. Pollut. 2019, 245 (2019), 98-110. https://doi.org/10.1016/j.envpol.2018.10.065.

(106) Laganà, P.; Caruso, G.; Corsi, I.; Bergami, E.; Venuti, V.; Majolino, D.; La Ferla, R.; Azzaro, M.; Cappello, S. Do Plastics Serve as a Possible Vector for the Spread of Antibiotic Resistance? First Insights from Bacteria Associated to a Polystyrene Piece from King George Island (Antarctica). Int. J. Hyg. Environ. Health 2019, 222 (1), 89-100. https://doi.org/10.1016/j.ijheh.2018.08.009.

(107) Jemec Kokalj, A.; Kuehnel, D.; Puntar, B.; Žgajnar Gotvajn, A.; Kalčikova, G. An 
Exploratory Ecotoxicity Study of Primary Microplastics versus Aged in Natural Waters and Wastewaters. Environ. Pollut. 2019, 254. https://doi.org/10.1016/j.envpol.2019.112980.

(108) Prata, J. C.; da Costa, J. P.; Lopes, I.; Duarte, A. C.; Rocha-Santos, T. Effects of Microplastics on Microalgae Populations: A Critical Review. Sci. Total Environ. 2019, 665, 400-405. https://doi.org/10.1016/j.scitotenv.2019.02.132.

(109) Espinosa, C.; Esteban, M. Á.; Cuesta, A. Dietary Administration of PVC and PE Microplastics Produces Histological Damage, Oxidative Stress and Immunoregulation in European Sea Bass (Dicentrarchus Labrax L.). Fish Shellfish Immunol. 2019, 95, 574-583. https://doi.org/10.1016/j.fsi.2019.10.072.

(110) Green, D. S.; Colgan, T. J.; Thompson, R. C.; Carolan, J. C. Exposure to Microplastics Reduces Attachment Strength and Alters the Haemolymph Proteome of Blue Mussels (Mytilus Edulis). Environ. Pollut. 2019, 246, 423-434. https://doi.org/10.1016/j.envpol.2018.12.017.

(111) Pannetier, P.; Cachot, J.; Clérandeau, C.; Faure, F.; Van Arkel, K.; de Alencastro, L. F.; Levasseur, C.; Sciacca, F.; Bourgeois, J.-P.; Morin, B. Toxicity Assessment of Pollutants Sorbed on Environmental Sample Microplastics Collected on Beaches: Part I-Adverse Effects on Fish Cell Line. Environ. Pollut. 2019, 248, 1088-1097. https://doi.org/10.1016/j.envpol.2018.12.091.

(112) Rezania, S.; Park, J.; Md Din, M. F.; Mat Taib, S.; Talaiekhozani, A.; Kumar Yadav, K.; Kamyab, H. Microplastics Pollution in Different Aquatic Environments and Biota: A Review of Recent Studies. Mar. Pollut. Bull. 2018, 133, 191-208. https://doi.org/10.1016/j.marpolbul.2018.05.022.

(113) Cormier, B.; Batel, A.; Cachot, J.; Bégout, M.-L.; Braunbeck, T.; Cousin, X.; Keiter, S. H. Multi-Laboratory Hazard Assessment of Contaminated Microplastic Particles by Means of Enhanced Fish Embryo Test With the Zebrafish (Danio Rerio). Front. Environ. Sci. 2019, 7. https://doi.org/10.3389/fenvs.2019.00135. 
(114) Varó, I.; Perini, A.; Torreblanca, A.; Garcia, Y.; Bergami, E.; Vannuccini, M. L.; Corsi, I. Time-Dependent Effects of Polystyrene Nanoparticles in Brine Shrimp Artemia Franciscana at Physiological, Biochemical and Molecular Levels. Sci. Total Environ. 2019, 675, 570580. https://doi.org/10.1016/j.scitotenv.2019.04.157.

(115) Adam, V.; Yang, T.; Nowack, B. Toward an Ecotoxicological Risk Assessment of Microplastics: Comparison of Available Hazard and Exposure Data in Freshwaters. Environ. Toxicol. Chem. 2019, 38 (2), 436-447. https://doi.org/10.1002/etc.4323.

(116) de Sá, L. C.; Oliveira, M.; Ribeiro, F.; Rocha, T. L.; Futter, M. N. Studies of the Effects of Microplastics on Aquatic Organisms: What Do We Know and Where Should We Focus Our Efforts in the Future? Sci. Total Environ. 2018, 645, 1029-1039. https://doi.org/10.1016/j.scitotenv.2018.07.207.

(117) Prata, J. C. Airborne Microplastics: Consequences to Human Health? Environ. Pollut. 2018, 234, 115-126. https://doi.org/10.1016/j.envpol.2017.11.043.

(118) Veneman, W. J.; Spaink, H. P.; Brun, N. R.; Bosker, T.; Vijver, M. G. Pathway Analysis of Systemic Transcriptome Responses to Injected Polystyrene Particles in Zebrafish Larvae. Aquat. Toxicol. 2017, 190, 112-120. https://doi.org/10.1016/j.aquatox.2017.06.014.

(119) Shen, M.; Song, B.; Zhu, Y.; Zeng, G.; Zhang, Y.; Yang, Y.; Wen, X.; Chen, M.; Yi, H. Removal of Microplastics via Drinking Water Treatment: Current Knowledge and Future Directions. Chemosphere 2020, 251. https://doi.org/10.1016/j.chemosphere.2020.126612.

(120) Freeman, S.; Booth, A. M.; Sabbah, I.; Tiller, R.; Dierking, J.; Klun, K.; Rotter, A.; BenDavid, E.; Javidpour, J.; Angel, D. L. Between Source and Sea: The Role of Wastewater Treatment in Reducing Marine Microplastics. J. Environ. Manage. 2020, 266. https://doi.org/10.1016/j.jenvman.2020.110642.

(121) Akarsu, C.; Kumbur, H.; Gökdağ, K.; Kıdeyş, A. E.; Sanchez-Vidal, A. Microplastics Composition and Load from Three Wastewater Treatment Plants Discharging into Mersin Bay, North Eastern Mediterranean Sea. Mar. Pollut. Bull. 2020, 150. 
https://doi.org/10.1016/j.marpolbul.2019.110776.

(122) Boyle, D.; Catarino, A. I.; Clark, N. J.; Henry, T. B. Polyvinyl Chloride (PVC) Plastic Fragments Release $\mathrm{Pb}$ Additives That Are Bioavailable in Zebrafish. Environ. Pollut. 2020, 263. https://doi.org/10.1016/j.envpol.2020.114422.

(123) Keller, A. S.; Jimenez-Martinez, J.; Mitrano, D. M. Transport of Nano- And Microplastic through Unsaturated Porous Media from Sewage Sludge Application. Environ. Sci. Technol. 2020, 54 (2), 911-920. https://doi.org/10.1021/acs.est.9b06483.

(124) De Falco, F.; Cocca, M.; Guarino, V.; Gentile, G.; Ambrogi, V.; Ambrosio, L.; Avella, M. Novel Finishing Treatments of Polyamide Fabrics by Electrofluidodynamic Process to Reduce Microplastic Release during Washings. Polym. Degrad. Stab. 2019, 165, 110-116. https://doi.org/10.1016/j.polymdegradstab.2019.05.001.

(125) Olmos, S.; López-Castellanos, J.; Bayo, J. Are Advanced Wastewater Treatment Technologies a Solution for Total Removal of Microplastics in Treated Effluents? WIT Trans. Ecol. Environ. 2019, 229, 109-116. https://doi.org/10.2495/WRM190111.

(126) Sun, J.; Dai, X.; Wang, Q.; van Loosdrecht, M. C. M.; Ni, B. J. Microplastics in Wastewater Treatment Plants: Detection, Occurrence and Removal. Water Res. 2019, 152, 21-37. https://doi.org/10.1016/j.watres.2018.12.050.

(127) Tubić, A.; Lončarski, M.; Maletić, S.; Jazić, J. M.; Watson, M.; Tričković, J.; Agbaba, J. Significance of Chlorinated Phenols Adsorption on Plastics and Bioplastics during Water Treatment. Water (Switzerland) 2019, 11 (11). https://doi.org/10.3390/w11112358.

(128) Lares, M.; Ncibi, M. C. M. C.; Sillanpää, M. M.; Sillanpää, M. M. Intercomparison Study on Commonly Used Methods to Determine Microplastics in Wastewater and Sludge Samples. Environ. Sci. Pollut. Res. 2019, 26 (12), 12109-12122. https://doi.org/10.1007/s11356-01904584-6.

(129) Prata, J. C. Microplastics in Wastewater: State of the Knowledge on Sources, Fate and Solutions. Mar. Pollut. Bull. 2018, 129 (1), 262-265. 
https://doi.org/10.1016/j.marpolbul.2018.02.046.

(130) Lares, M.; Ncibi, M. C.; Sillanpää, M.; Sillanpää, M. Occurrence, Identification and Removal of Microplastic Particles and Fibers in Conventional Activated Sludge Process and Advanced MBR Technology. Water Res. 2018, 133, 236-246.

https://doi.org/10.1016/j.watres.2018.01.049.

(131) Kalčíková, G.; Alič, B.; Skalar, T.; Bundschuh, M.; Gotvajn, A. Ž. Wastewater Treatment Plant Effluents as Source of Cosmetic Polyethylene Microbeads to Freshwater. Chemosphere 2017, 188, 25-31. https://doi.org/10.1016/j.chemosphere.2017.08.131.

(132) Belzagui, F.; Crespi, M.; Álvarez, A.; Gutiérrez-Bouzán, C.; Vilaseca, M. Microplastics’ Emissions: Microfibers’ Detachment from Textile Garments. Environ. Pollut. 2019, 248, 1028-1035. https://doi.org/10.1016/j.envpol.2019.02.059.

(133) Hernandez, E.; Nowack, B.; Mitrano, D. M. Polyester Textiles as a Source of Microplastics from Households: A Mechanistic Study to Understand Microfiber Release during Washing. Environ. Sci. Technol. 2017, 51 (12), 7036-7046. https://doi.org/10.1021/acs.est.7b01750.

(134) Carney Almroth, B. M.; Åström, L.; Roslund, S.; Petersson, H.; Johansson, M.; Persson, N.K. Quantifying Shedding of Synthetic Fibers from Textiles; a Source of Microplastics Released into the Environment. Environ. Sci. Pollut. Res. 2018, 25 (2), 1191-1199. https://doi.org/10.1007/s11356-017-0528-7.

(135) Díez-Minguito, M.; Bermúdez, M.; Gago, J.; Carretero, O.; Viñas, L. Observations and Idealized Modelling of Microplastic Transport in Estuaries: The Exemplary Case of an Upwelling System (Ría de Vigo, NW Spain). Mar. Chem. 2020, 222. https://doi.org/10.1016/j.marchem.2020.103780.

(136) Allen, S.; Allen, D.; Phoenix, V. R.; Le Roux, G.; Durántez Jiménez, P.; Simonneau, A.; Binet, S.; Galop, D. Atmospheric Transport and Deposition of Microplastics in a Remote Mountain Catchment. Nat. Geosci. 2019, 12 (5), 339-344. https://doi.org/10.1038/s41561019-0335-5. 
(137) Hartmann, N. B.; Rist, S.; Bodin, J.; Jensen, L. H. S.; Schmidt, S. N.; Mayer, P.; Meibom, A.; Baun, A. Microplastics as Vectors for Environmental Contaminants: Exploring Sorption, Desorption, and Transfer to Biota. Integr. Environ. Assess. Manag. 2017, 13 (3), 488-493. https://doi.org/10.1002/ieam.1904.

(138) Kedzierski, M.; Le Tilly, V.; Bourseau, P.; Bellegou, H.; César, G.; Sire, O.; Bruzaud, S. Microplastics Elutriation System. Part A: Numerical Modeling. Mar. Pollut. Bull. 2017, 119 (2), 151-161. https://doi.org/10.1016/j.marpolbul.2017.04.060.

(139) Hildebrandt, L.; Mitrano, D. M.; Zimmermann, T.; Pröfrock, D. A Nanoplastic Sampling and Enrichment Approach by Continuous Flow Centrifugation. Front. Environ. Sci. 2020, 8. https://doi.org/10.3389/fenvs.2020.00089.

(140) da Costa, J. P.; Santos, P. S. M.; Duarte, A. C.; Rocha-Santos, T. (Nano)Plastics in the Environment - Sources, Fates and Effects. Sci. Total Environ. 2016, 566-567, 15-26. https://doi.org/10.1016/j.scitotenv.2016.05.041.

(141) Piccardo, M.; Renzi, M.; Terlizzi, A. Nanoplastics in the Oceans: Theory, Experimental Evidence and Real World. Mar. Pollut. Bull. 2020, 157. https://doi.org/10.1016/j.marpolbul.2020.111317.

(142) Venâncio, C.; Ferreira, I.; Martins, M. A.; Soares, A. M. V. M.; Lopes, I.; Oliveira, M. The Effects of Nanoplastics on Marine Plankton: A Case Study with Polymethylmethacrylate. Ecotoxicol. Environ. Saf. 2019, 184. https://doi.org/10.1016/j.ecoenv.2019.109632.

(143) Galloway, T. S. Micro- and Nano-Plastics and Human Health. In Marine Anthropogenic Litter; Springer International Publishing, 2015; pp 343-366. https://doi.org/10.1007/978-3319-16510-3_13.

(144) Miranda, M. N.; Silva, A. M. T.; Pereira, M. F. R. Microplastics in the Environment: A DPSIR Analysis with Focus on the Responses. Sci. Total Environ. 2020, 718. https://doi.org/10.1016/j.scitotenv.2019.134968.

(145) Birch, Q. T.; Potter, P. M.; Pinto, P. X.; Dionysiou, D. D.; Al-Abed, S. R. Sources, 
Transport, Measurement and Impact of Nano and Microplastics in Urban Watersheds. Rev. Environ. Sci. Biotechnol. 2020, 19 (2), 275-336. https://doi.org/10.1007/s11157-020-09529$\mathrm{x}$.

(146) Steensgaard, I.; Syberg, K.; Rist, S.; Hartmann, N.; Boldrin, A.; Hansen, S. F. From Macroto Microplastics - Analysis of EU Regulation along the Life Cycle of Plastic Bags. Environ. Pollut. 2017, 224, 289-299. https://doi.org/10.1016/j.envpol.2017.02.007.

(147) Everaert, G.; Van Cauwenberghe, L.; De Rijcke, M.; Koelmans, A. A. A.; Mees, J.; Vandegehuchte, M.; Janssen, C. R. C. R. Risk Assessment of Microplastics in the Ocean: Modelling Approach and First Conclusions. Environ. Pollut. 2018, 242, 1930-1938. https://doi.org/10.1016/j.envpol.2018.07.069.

(148) Scott-Fordsmand, J. J.; Navas, J. M.; Hund-Rinke, K.; Nowack, B.; Amorim, M. J. B. Nanomaterials to Microplastics: Swings and Roundabouts. Nano Today 2017, 17, 7-10. https://doi.org/10.1016/j.nantod.2017.09.002.

(149) Syberg, K.; Khan, F. R.; Selck, H.; Palmqvist, A.; Banta, G. T.; Daley, J.; Sano, L.; Duhaime, M. B. Microplastics: Addressing Ecological Risk through Lessons Learned. Environ. Toxicol. Chem. 2015, 34 (5), 945-953. https://doi.org/10.1002/etc.2914.

(150) Amorim, M. J. B.; Lin, S.; Schlich, K.; Navas, J. M.; Brunelli, A.; Neubauer, N.; Vilsmeier, K.; Costa, A. L.; Gondikas, A.; Xia, T.; Nel, A.; Wohlleben, W. Environmental Impacts by Fragments Released from Nanoenabled Products: A Multiassay, Multimaterial Exploration by the SUN Approach. Environ. Sci. Technol. 2018, 52 (3), 1514-1524. https://doi.org/10.1021/acs.est.7b04122. 
